\title{
Symbiotic potential and survival of native rhizobia kept on different carriers
}

\author{
Víctor Manuel Ruíz-Valdiviezo ${ }^{1}$, Lucía María Cristina Ventura Canseco ${ }^{1}$, \\ Luis Antonio Castillo Suárez ${ }^{1}$, Federico Antonio Gutiérrez-Miceli ${ }^{1}$, Luc Dendooven ${ }^{2}$, \\ Reiner Rincón-Rosales ${ }^{1}$ \\ ${ }^{1}$ Laboratory of Biotechnology, Instituto Tecnológico de Tuxtla Gutiérrez, Chiapas, México. \\ ${ }^{2}$ Laboratory of Soil Ecology, Abacus, Cinvestav, DF, México.
}

Submitted: October 23, 2013; Approved: August 15, 2014.

\begin{abstract}
Native rhizobia are ideal for use as commercial legume inoculants. The characteristics of the carrier used to store the inoculants are important for the survival and symbiotic potential of the rhizobia. The objective of this study was to investigate the effects of peat (PEAT), perlite sugarcane bagasse (PSB), carboxymethyl cellulose plus starch (CMCS), and yeast extract mannitol supplemented with mannitol (YEMM) on the survival, nodulation potential and $\mathrm{N}_{2}$ fixation capacity of the native strains Sinorhizobium mexicanum ITTG R $7^{\mathrm{T}}$ and Rhizobium calliandrae $\mathrm{LBP} 2-1^{\mathrm{T}}$ and of the reference strain Rhizobium etli CFN42 ${ }^{\mathrm{T}}$. A factorial design (4 $\left.\times 3\right)$ with four repetitions was used to determine the symbiotic potential of the rhizobial strains. The survival of the strains was higher for PEAT ( $46 \%$ for strain LBP2- $1^{\mathrm{T}}, 167 \%$ for strain CFN $42^{\mathrm{T}}$ and $219 \%$ for strain ITTG R $7^{\mathrm{T}}$ ) than for the other carriers after 240 days, except for CFN42 ${ }^{\mathrm{T}}$ kept on CMCS $(225 \%)$. All the strains kept on the different carriers effectively nodulated common bean, with the lowest number of nodules found (5 nodules) when CFN42 ${ }^{\mathrm{T}}$ was kept on CMCS and with the highest number of nodules found (28 nodules) when ITTG $\mathrm{R} 7^{\mathrm{T}}$ was kept on PSB. The nitrogenase activity was the highest for ITTG $\mathrm{R} 7^{\mathrm{T}}$ kept on PEAT $\left(4911 \mu \mathrm{mol} \mathrm{C}_{2} \mathrm{H}_{4}\right.$ per fresh weight nodule $\left.\mathrm{h}^{-1}\right)$; however, no activity was found when the strains were kept on YEMM. Thus, the survival and symbiotic potential of the rhizobia depended on the carrier used to store them.
\end{abstract}

Key words: rhizobia, inoculants, nodulation, nitrogen fixation, carrier.

\section{Introduction}

The inoculation of the plant rhizosphere or seeds with rhizobia, i.e., $\mathrm{N}_{2}$-fixing bacteria, to stimulate plant growth has been used for a long time (Lopez-Lopez et al., 2010). Symbiosis between the $\mathrm{N}_{2}$-fixing bacteria and the plant reduces the need for inorganic $\mathrm{N}$ fertilizer applications. The use of native rhizobia has been recommended because these bacteria adapt easily to the specific environmental conditions, which facilitates their survival and the successful nodulation of the host plant (Romdhane et al., 2008; Topre et al., 2011).

The rhizobial inoculants are kept on a support or a carrier so that these bacteria can be stored for a long period and used when required (Albareda et al., 2008). The mate- rial used as a carrier should allow the survival of the rhizobia and preserve their capacity to form nodules and to fix $\mathrm{N}_{2}$. A high-grade carrier should have high water retention and stable $\mathrm{pH}$, and it should be inexpensive, constitutive, nontoxic for the strain or environment and easy to sterilize (Swelim et al., 2010). Peat is one of the most commonly used carriers (Albareda et al., 2008), although other substrates have been used. For instance, sugarcane bagasse and perlite were tested as carriers for Bradyrhizobium japonicum strain CB1809 (Khavazi et al., 2007). When the carrier was stored at $4{ }^{\circ} \mathrm{C}$ for six months, the bacterial inoculant survival was high, and a density of $10^{9}$ cells g $^{-1}$ was maintained. Mixtures of carboxymethyl cellulose and starch maintained a stable cellular concentration of $B$. japonicum strain BR3267 when stored at $20-26^{\circ} \mathrm{C}$ for 180 
days (Fernandes-Júnior et al., 2009). A stable rhizobia population of Sinorhizobium fredii SMH12 was also obtained when the cells where kept in yeast extract mannitol supplemented with $1 \%$ mannitol (YEMM) at $25^{\circ} \mathrm{C}$ for 100 days (Albareda et al., 2008).

While these carriers were able to maintain the rhizobia population, considering other factors, such as the stability and viability of the biofertilizer, which might vary between the strains used as biofertilizer, is necessary (Fernandes-Júnior et al., 2012). Studying how the different carriers affect the biological activity of microorganisms, the infectivity of rhizobia inoculants and the symbiotic potential of the strains used as inoculants is also desirable (Hungria et al., 2005). Therefore, the objective of the present study was to determine the effects of peat (PEAT) and perlite sugarcane bagasse (PSB) as solid carriers and of carboxymethyl cellulose plus starch (CMCS) and YEMM as liquid carriers on the survival, potential for nodulation of the common bean (Phaseolus vulgaris L.) and capacity for $\mathrm{N}_{2}$ fixation of the native strains Sinorhizobium mexicanum ITTG R7 ${ }^{\mathrm{T}}$ and Rhizobium calliandrae LBP2-1 ${ }^{\mathrm{T}}$ and of the reference strain Rhizobium etli CFN42 ${ }^{\mathrm{T}}$.

\section{Materials and Methods}

\section{Bacterial strains}

The native rhizobia used in this study were $S$. mexicanum ITTG $\mathrm{R} 7^{\mathrm{T}}$ (Lloret et al., 2007) and $R$. calliandrae LBP2-1 ${ }^{\mathrm{T}}$ (Rincón-Rosales et al., 2013) obtained from the Instituto Tecnológico de Tuxtla Gutiérrez (Chiapas, Mexico). These strains are characterized by rapid growth, high potentials for nitrogen fixation and activity under saline conditions and high aluminum concentrations. The reference strain $R$. etli CFN $42^{\mathrm{T}}$ was provided by the Centro de Ciencias Genómicas (Cuernavaca, México). $R$. etli CFN42 ${ }^{\mathrm{T}}$, which has been used commercially in Mexico as an inoculant, is characterized by a high nodulation potential (Martínez-Romero, 2003). The strains were grown in yeast extract mannitol (YEM) medium (Vincent, 1970) at $28{ }^{\circ} \mathrm{C}$ and then stored at $4{ }^{\circ} \mathrm{C}$ until use.

\section{Preparation of the carriers}

The carriers used in this study were 1) PSB and 2) PEAT as solid carriers and 3) CMCS and 4) YEMM as liquid carriers. Sphagnum peat (PROMIX 1100, Quebec, Canada) was used as a reference carrier (Albareda et al., 2008). The carriers PSB and PEAT were first ground and then sieved (mesh size 100). The carrier PSB had a 4:1 (sugarcane bagasse:perlite) ratio (Khavazi et al., 2007). The $\mathrm{pH}$ of the peat was adjusted to 6.7 using $35 \mathrm{~g} \mathrm{Na}_{2} \mathrm{CO}_{3}$ for each $100 \mathrm{~g}$ material. The carriers PSB and PEAT were sterilized at $121^{\circ} \mathrm{C}$ for $20 \mathrm{~min}$.

The CMCS carrier was prepared by mixing carboxymethyl cellulose and starch (ratio 60:40 w/w) and amended with $\mathrm{MgO}$ at $1 \%$ to achieve a final concentration
$1.28 \% \mathrm{w} / \mathrm{v}$ and a pH of 6.7 (Fernandes-Júnior et al., 2009). The YEMM carrier was prepared with $1.0 \mathrm{~g}$ yeast extract, $0.1 \mathrm{~g} \mathrm{NaCl}, 0.5 \mathrm{~g} \mathrm{~K}_{2} \mathrm{HPO}_{4}, 0.2 \mathrm{~g} \mathrm{MgSO}_{4} 7 \mathrm{H}_{2} \mathrm{O}$, and $20 \mathrm{~g}$ mannitol $\mathrm{L}^{-1}$ distilled water and adjusted to $\mathrm{pH}$ 6.7. Both carriers were sterilized at $121{ }^{\circ} \mathrm{C}$ for 15 min (Albareda et al., 2008).

The physical characteristics of the carriers were determined each time a sample of the rhizobia was taken. The $\mathrm{pH}$ and water holding capacity (WHC) were determined for the solid carriers PEAT and PSB (Somasegaran and Hoben, 1985), and the $\mathrm{pH}$ and viscosity were determined for the CMCS and YEMM carriers (FernandesJúnior et al., 2009).

\section{Biofertilizer production}

The biofertilizers combined the four carriers and the three strains ITTG R $7^{\mathrm{T}}, \mathrm{LBP} 2-1^{\mathrm{T}}$ and $\mathrm{CFN} 42^{\mathrm{T}}$. Erlenmeyer flasks (2 L) containing $800 \mathrm{~mL}$ YEM broth (Albareda et al., 2008 ) were inoculated with $10 \%$ (v/v) of the corresponding microbial suspension and aired with $2 \mathrm{~L} \mathrm{~min}^{-1}$ sterile air for $27 \mathrm{~h}$. All the carriers were inoculated with $1.5 \mathrm{~mL}$ inoculant $\mathrm{g}^{-1}$ under sterile conditions, i.e., $>2 \times 10^{9}$ cells g ${ }^{-1}$. Twentyfive grams solid and $25 \mathrm{~mL}$ liquid biofertilizer were added to sterilized polypropylene bags $(20 \mathrm{~cm} \times 30 \mathrm{~cm})$ and stored at $25^{\circ} \mathrm{C}$ until use.

\section{Rhizobial survival determination and biofertilization test}

The number of viable rhizobia was determined by serial dilution and plate counting on YEM agar (pH 6.7) after 14, 60, 120, 180 and 240 days (Vincent, 1970). Seeds of the common bean (Phaseolus vulgaris L.) cultivar Jamapa previously impregnated with $40 \%$ Arabic gum (SigmaAldrich, St. Louis, MO, USA) were inoculated with PSB or PEAT containing $8 \mathrm{~g}$ inoculant $100 \mathrm{~g}^{-1}$ seed. Biofertilizers formulated with CMCS or YEMM were directly applied to the seeds at $8 \mathrm{~mL}$ inoculant $100 \mathrm{~g}^{-1}$ seed. The treated seeds were sown in plastic pots containing sterilized vermiculite. Four replicate pots were used and arranged in a completely randomized design. The plants were grown in a climate chamber at $25{ }^{\circ} \mathrm{C}$ using photoperiods of $16 \mathrm{~h}$ light $/ 8 \mathrm{~h}$ darkness (Rincón-Rosales et al., 2009) and watered with a $\mathrm{N}$-free nutritive Fahraeus solution (Fahraeus, 1957). The shoot dry weight, number of nodules and shoot $\mathrm{N}$ content were determined after 240 days. The $\mathrm{N}_{2}$-fixing capacity was determined using the acetylene reduction assay. Ethylene was determined using a Varian-3300 (Pampa, TX, USA) gas chromatograph fitted with a flame ionization detector (FID) and a Porapak N column $(300 \times 0.1 \mathrm{~cm})$ at $50-70{ }^{\circ} \mathrm{C}$ using nitrogen as carrier gas $\left(50 \mathrm{~mL} \mathrm{~min}{ }^{-1}\right)$ (Ruiz-Valdiviezo et al., 2009).

\section{Statistical analysis}

Significant differences between the shoot dry weight, number of nodules, nitrogenase activity and shoot nitrogen 
content of the legume $P$. vulgaris L. because of the application of the different rhizobia kept on different carriers were determined using analysis of variance (ANOVA) with Tukey's test. Relationships between physical characteristics of the carriers and strain viability were determined using the Pearson correlation coefficients. All analyses were performed using StatGraphics Centurion version XV.2 software (Warrenton, Virginia, USA).

\section{Results and Discussion}

\section{Physical characteristics of the carriers}

The $\mathrm{pH}$ of the peat used in this study was 3.8. This carrier normally has a $\mathrm{pH}$ ranging from 3.5 to 4.5 (Somasegaran and Hoben, 1985). The $\mathrm{pH}$ was adjusted to 6.7 with $35 \mathrm{~g} \mathrm{Na}_{2} \mathrm{CO}_{3}$ so that a near neutral $\mathrm{pH}$ was obtained, which maintains the viability of the rhizobia (Vincent, 1970). The WHC of peat in this study was $282 \%$, which is higher than the $120 \%$ reported by Somasegaran and Hoben (1985). The origin of the peat might have resulted in a higher WHC (Tittabutr et al., 2007). The pH of the PSB was 7.7, which is appropriate for the growth of rhizobia (Albareda et al., 2008). The WHC of the PSB was $512 \%$, which is higher than the value reported for perlite $(400 \%)$ (Khavazi et al., 2007). The high WHC of both carriers favors the enzymatic processes involved in the degradation of the organic material that provide important nutrients such as phosphorus for the rhizobial bacteria.

The carrier CMCS, which is prepared by mixing carboxymethyl cellulose and starch, allowed the formation of a polymer with a viscosity of $414 \mathrm{cP}$. This viscosity favors the survival of the rhizobia. However, the initial $\mathrm{pH}$ was 10.8, which decreases the viability of the bacteria; thus, $\mathrm{MgO}$ was added. This addition adjusted the $\mathrm{pH}$ to 6.7 , which is the $\mathrm{pH}$ recommended for rhizobia carriers (Fernandes-Júnior et al., 2009). The YEMM liquid carrier ( $\mathrm{pH}$ 6.7) had a viscosity of only $1.11 \mathrm{cP}$. This result suggested that this liquid carrier might decrease the survival of the rhizobia as reported by Tittabutr et al. (2007) and by Albareda et al. (2008).

\section{Survival of rhizobia strains in different carriers}

The survival of strains $S$. mexicanum ITTG $\mathrm{R} 7^{\mathrm{T}}, R$. calliandrae $\mathrm{LBP} 2-1^{\mathrm{T}}$ and $R$. etli $\mathrm{CFN} 42^{\mathrm{T}}$ was determined in two solid and two liquid carriers kept at $25^{\circ} \mathrm{C}$ for 240 days (Figure 1). The survival of the rhizobia strains differed between the carriers. After 240 days, the survival of the rhizobia was higher in the solid carriers PEAT and PSB than in the liquid carriers (Figure $1 \mathrm{a}$ and $1 \mathrm{~b}$ ). In the PEAT and PSB carriers, the cellular concentration of all strains remained at $2 \times 10^{9}$ cells $\mathrm{g}^{-1}$, which is recommended for the production of biofertilizers (Ben Rebah et al., 2007). PSB and PEAT contain high concentrations of organic material and essential nutrients (Khavazi et al., 2007), maintaining the viability of the rhizobia.
The cellular concentration of the $R$. etli $\mathrm{CFN} 42^{\mathrm{T}}$ strain significantly decreased $(\mathrm{p}<0.05)$ in the liquid carrier YEMM after 60 days (Figure 1c), while the cellular concentrations of the ITTG R $7^{\mathrm{T}}$ and LBP $2-1^{\mathrm{T}}$ strains remained at $>10^{8}$ cells $\mathrm{g}^{-1}$. In the CMCS carrier, the strains main-

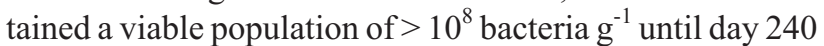
(Figure 1d), which is sufficient for use as biofertilizers (Fernandes-Júnior et al., 2009). The high survival of the rhizobia in this carrier might be due to its rheological and chemical characteristics, e.g., high viscosity and hygroscopicity. Flores da Silva et al. (2012) reported that survival of Gluconacetobacter diazotrophicus and Azospirillum amazonense was $10^{9} \mathrm{cfu} \mathrm{mL}^{-1}$ in a medium of CMC-starch supplemented with $\mathrm{MgO}$ after 120 days.

Several researchers (e.g., Deaker et al., 2004; Fernandes-Júnior et al., 2009) reported that different physical factors affect the viability and survival of rhizobia in the carrier. In the present study, the $\mathrm{pH}, \mathrm{WHC}$ and viscosity were monitored to determine their possible effects on the survival and viability of the rhizobia studied (Table 1). After 240 days, the $\mathrm{pH}$ of the YEMM liquid carrier decreased from 6.7 to 4.9 when inoculated with the $\mathrm{CFN} 42^{\mathrm{T}}$ strain; to 6.4, with the ITTG R $7^{\mathrm{T}}$ strain; and to 4.8 , with the LBP2-1 ${ }^{\mathrm{T}}$ strain. The viability of the CFN $42^{\mathrm{T}}$ and ITTG $\mathrm{R} 7^{\mathrm{T}}$ strains and their concentrations were negatively affected by a decrease in $\mathrm{pH}$ during storage, thus decreasing their symbiotic potentials.

Pearson correlation analysis showed that the $\mathrm{pH}$ and viscosity of the liquid carriers significantly affected the viability of strain LBP $2-1^{\mathrm{T}}$ and that only the WHC of the PSB affected viability $(\mathrm{p}<0.05)$ (Table 2$)$. The viability of ITTG $R 7^{\mathrm{T}}$ strain significantly correlated with the viscosity of the liquid carrier and with the $\mathrm{pH}$ of the PEAT carrier $(p<0.05)$. The viability of the CFN $42^{\mathrm{T}}$ strain significantly correlated only with the $\mathrm{pH}$ of the YEMM carrier and with the viscosity of the CMCS carrier $(\mathrm{p}<0.05)$.

Several strains of Rhizobium produce exopolysaccharides (EPSs), which facilitate symbiosis (Luque-Castellane et al., 2014). In the present study, EPS production was higher for the CFN42 ${ }^{\mathrm{T}}$ strain than for the native ITTG $R 7^{\mathrm{T}}$ and LBP $2-1^{\mathrm{T}}$ strains when kept in the YEMM carrier (data not shown). Rhizobial EPSs are composed of different types of monosaccharides and secreted into the environment. Rhizobium leguminosarum strains produce acidic EPSs that are composed of glucose, glucuronic acid and galactose, which may cause changes in the $\mathrm{pH}$ of the culture medium (Skorupska et al., 2006). Our results indicated that the exopolysaccharides produced by the rhizobia strains used in the present study decreased the $\mathrm{pH}$, thereby reducing the viability of the bacteria in the carrier.

When the CMCS support was inoculated with the CFN42 ${ }^{\mathrm{T}}$, ITTG $\mathrm{R} 7^{\mathrm{T}}$ or LBP2-1 ${ }^{\mathrm{T}}$ strain, the $\mathrm{pH}$ was maintained between 6.7 and 7.2 (Table 1), which is suitable for the growth of rhizobia cells. In the CMCS carrier, the viscosity decreased significantly from $190.5 \mathrm{cP}$ to $3.1 \mathrm{cP}$ for 

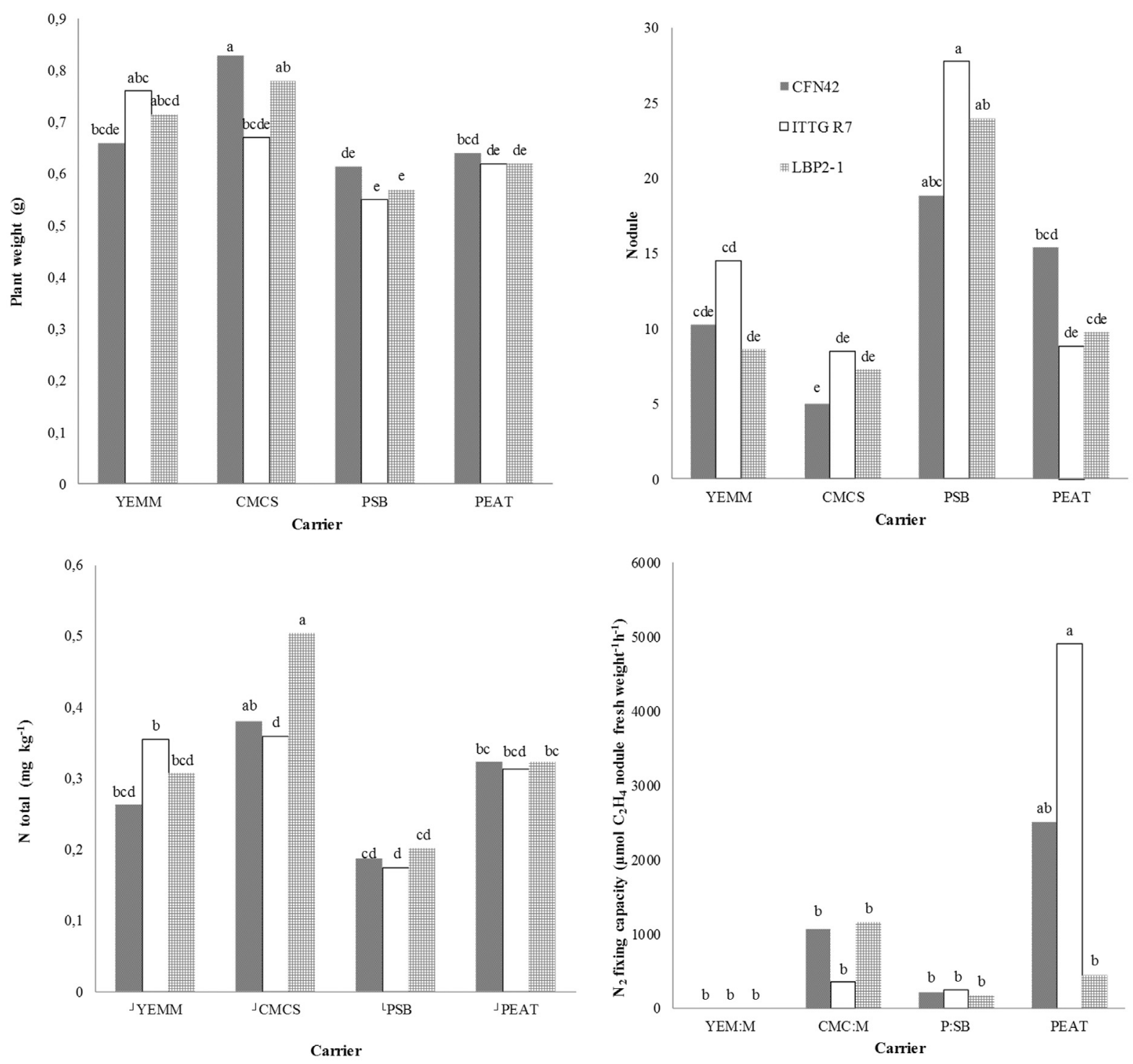

Figure 1 - Survival of the ITTG R $7^{\mathrm{T}}$ and LBP2- $1^{\mathrm{T}}$ strains and of the reference strain CFN42 ${ }^{\mathrm{T}}$ in the carriers a) PEAT, b) PSB, c) YEMM and d) CMCS stored at $25^{\circ} \mathrm{C}$ for 240 days.

the CFN42 ${ }^{\mathrm{T}}$ strain, to $7.7 \mathrm{cP}$ for ITTG R $7^{\mathrm{T}}$ and to $6.6 \mathrm{cP}$ for LBP2- $1^{\mathrm{T}}(\mathrm{p}<0.05)$. These results indicated that the viscosity affected the viability of the ITTG R7 ${ }^{\mathrm{T}}$ and LBP2-1 ${ }^{\mathrm{T}}$ strains, which could be because the rhizobial cells used the carrier as a C source (Fernandes-Júnior et al., 2009).

The WHC and $\mathrm{pH}$ are the factors that primarily affect the survival of rhizobia strains in carriers (Ben Rebah et al., 2002). In the present study, the $\mathrm{pH}$ remained stable in the inoculated PSB carrier. However, the WHC decreased significantly from an initial value of $137 \%$ to $23 \%$ when the $\mathrm{CFN}_{2}{ }^{\mathrm{T}}$ strain was added, to $58 \%$ when the ITTG $\mathrm{R} 7^{\mathrm{T}}$ strain was added and to $37 \%$ when the LBP2-1 ${ }^{\mathrm{T}}$ strain was added (Table 1). The high amount of water retained in the PSB carrier favored the enzymatic processes involved in the degradation of organic matter that generates nutrients required for bacterial growth (Ben Rebah et al., 2007).
Peat is the most commonly used carrier to store rhizobia used as biofertilizer (Khavazi et al., 2007; Kaira et al., 2010). This carrier is excellent for storing microorganisms because peat has a high WHC, chemical and physical uniformity, a lack of toxic compounds and no environmental risk (Ferreira and Castro, 2005; Ferreira et al., 2010). In the present study, the WHC values remained constant when peat was inoculated with the ITTG $\mathrm{R} 7^{\mathrm{T}}$ strain; the viability of this strain increased significantly compared with the other evaluated strains during 240 days of storage $(\mathrm{p}<0.05)$ (Table 1). 


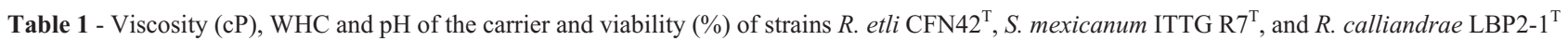
kept on PEAT, PSB, CMCS, and YEMM for 240 days.

\begin{tabular}{|c|c|c|c|c|c|c|c|c|c|c|}
\hline \multirow[b]{2}{*}{ Carrier } & \multirow[b]{2}{*}{ Days } & \multicolumn{3}{|c|}{ Rhizobium etli $\mathrm{CFN} 42^{\mathrm{T}}$} & \multicolumn{3}{|c|}{ Sinorhizobium mexicanum ITTG $\mathrm{R} 7^{\mathrm{T}}$} & \multicolumn{3}{|c|}{ Rhizobium calliandrae LBP2-1 $1^{\mathrm{T}}$} \\
\hline & & $\mathrm{pH}$ & Viscosity & Viability & $\mathrm{pH}$ & Viscosity & Viability & $\mathrm{pH}$ & Viscosity & Viability \\
\hline \multirow[t]{6}{*}{ YEMM } & 0 & $6.7 \mathrm{~A}^{\mathrm{a}}$ & $0.8 \mathrm{C}$ & $100 \mathrm{~A}$ & $6.7 \mathrm{AB}$ & $0.8 \mathrm{~A}$ & $100 \mathrm{~A}$ & $6.6 \mathrm{~A}$ & $0.8 \mathrm{~A}$ & $100 \mathrm{~A}$ \\
\hline & 14 & $5.5 \mathrm{~B}$ & $1.5 \mathrm{~A}$ & $12 \mathrm{~B}$ & $5.6 \mathrm{E}$ & $0.9 \mathrm{~A}$ & $15 \mathrm{~B}$ & $5.8 \mathrm{AB}$ & $1.1 \mathrm{~A}$ & $36 \mathrm{~B}$ \\
\hline & 60 & $4.8 \mathrm{D}$ & $0.9 \mathrm{BC}$ & $5 \mathrm{C}$ & $6.2 \mathrm{D}$ & $1.1 \mathrm{~A}$ & $15 \mathrm{~B}$ & $5.7 \mathrm{AB}$ & $1.2 \mathrm{~A}$ & $4 \mathrm{C}$ \\
\hline & 120 & $4.8 \mathrm{D}$ & $0.8 \mathrm{C}$ & $0 \mathrm{D}$ & $6.5 \mathrm{BC}$ & $1.2 \mathrm{~A}$ & $8 \mathrm{C}$ & $5.3 \mathrm{BC}$ & $1.2 \mathrm{~A}$ & $3 \mathrm{C}$ \\
\hline & 180 & $5.1 \mathrm{C}$ & $0.9 \mathrm{BC}$ & $0 \mathrm{D}$ & $6.7 \mathrm{~A}$ & $1.5 \mathrm{~A}$ & $1 \mathrm{D}$ & $6.1 \mathrm{~A}$ & $1.6 \mathrm{~A}$ & $1 \mathrm{C}$ \\
\hline & 240 & $4.9 \mathrm{CD}$ & $1.0 \mathrm{~B}$ & $0 \mathrm{D}$ & $6.4 \mathrm{CD}$ & $1.5 \mathrm{~A}$ & $7 \mathrm{C}$ & $4.8 \mathrm{C}$ & $1.3 \mathrm{~A}$ & $1 \mathrm{C}$ \\
\hline \multirow[t]{6}{*}{ CMCS } & 0 & $6.7 \mathrm{C}$ & $190.5 \mathrm{~A}$ & $100 \mathrm{C}$ & $6.8 \mathrm{~B}$ & $190.5 \mathrm{~A}$ & $100 \mathrm{~A}$ & $6.7 \mathrm{E}$ & $190.5 \mathrm{~A}$ & $100 \mathrm{~A}$ \\
\hline & 14 & $6.7 \mathrm{C}$ & $7.2 \mathrm{C}$ & $295 \mathrm{~B}$ & $6.7 \mathrm{~B}$ & $16.7 \mathrm{BC}$ & $30 \mathrm{~B}$ & $7.4 \mathrm{C}$ & $24.3 \mathrm{BC}$ & $16 \mathrm{~B}$ \\
\hline & 60 & $6.7 \mathrm{C}$ & $38.7 \mathrm{~B}$ & $269 \mathrm{~B}$ & $7.4 \mathrm{~A}$ & $33.2 \mathrm{~B}$ & $27 \mathrm{~B}$ & $7.7 \mathrm{~B}$ & $34.6 \mathrm{~B}$ & $20 \mathrm{~B}$ \\
\hline & 120 & $7.1 \mathrm{AB}$ & $9.0 \mathrm{C}$ & $219 \mathrm{~B}$ & $7.6 \mathrm{~A}$ & $30.5 \mathrm{~B}$ & $6 \mathrm{C}$ & $7.9 \mathrm{~A}$ & $30.6 \mathrm{BC}$ & $4 \mathrm{C}$ \\
\hline & 180 & $7.4 \mathrm{~A}$ & $4.9 \mathrm{C}$ & $507 \mathrm{~A}$ & $6.6 \mathrm{~B}$ & $7.7 \mathrm{C}$ & $2 \mathrm{C}$ & $7.7 \mathrm{AB}$ & $21.3 \mathrm{BC}$ & $5 \mathrm{C}$ \\
\hline & 240 & $7.6 \mathrm{~A}$ & $3.1 \mathrm{C}$ & $225 \mathrm{~B}$ & $7.6 \mathrm{~A}$ & $7.7 \mathrm{C}$ & $7 \mathrm{C}$ & $7.2 \mathrm{D}$ & $6.6 \mathrm{C}$ & $16 \mathrm{~B}$ \\
\hline Carrier & Days & $\mathrm{pH}$ & $\mathrm{WHC}^{\mathrm{b}}$ & Viability & $\mathrm{pH}$ & WHC & Viability & $\mathrm{pH}$ & WHC & Viability \\
\hline \multirow[t]{6}{*}{ PSB } & 0 & $7.7 \mathrm{~A}$ & $137 \mathrm{~A}$ & $100 \mathrm{~A}$ & $7.7 \mathrm{~B}$ & $123 \mathrm{~A}$ & $100 \mathrm{AB}$ & $7.8 \mathrm{~A}$ & $134 \mathrm{~A}$ & $100 \mathrm{~A}$ \\
\hline & 14 & $7.5 \mathrm{~B}$ & $137 \mathrm{~A}$ & $206 \mathrm{~A}$ & $7.9 \mathrm{~A}$ & $123 \mathrm{~A}$ & $93 \mathrm{AB}$ & $7.7 \mathrm{AB}$ & $133 \mathrm{~A}$ & $29 \mathrm{CD}$ \\
\hline & 60 & $7.2 \mathrm{C}$ & $113 \mathrm{AB}$ & $106 \mathrm{~A}$ & $7.3 \mathrm{C}$ & $150 \mathrm{~A}$ & $122 \mathrm{~A}$ & $7.0 \mathrm{D}$ & $110 \mathrm{AB}$ & $54 \mathrm{BC}$ \\
\hline & 120 & $7.2 \mathrm{C}$ & $90 \mathrm{BC}$ & $153 \mathrm{~A}$ & $7.3 \mathrm{C}$ & $103 \mathrm{~A}$ & $114 \mathrm{AB}$ & $7.0 \mathrm{D}$ & $76 \mathrm{BC}$ & $67 \mathrm{~B}$ \\
\hline & 180 & $7.2 \mathrm{C}$ & $67 \mathrm{C}$ & $211 \mathrm{~A}$ & $7.3 \mathrm{C}$ & $156 \mathrm{~A}$ & $71 \mathrm{~B}$ & $7.4 \mathrm{BC}$ & $60 \mathrm{C}$ & $37 \mathrm{CD}$ \\
\hline & 240 & $7.2 \mathrm{C}$ & $23 \mathrm{D}$ & $139 \mathrm{~A}$ & $7.3 \mathrm{C}$ & $58 \mathrm{~A}$ & $21 \mathrm{C}$ & $7.3 \mathrm{CD}$ & $37 \mathrm{C}$ & $13 \mathrm{D}$ \\
\hline \multirow[t]{6}{*}{ PEAT } & 0 & $6.7 \mathrm{~B}$ & $120 \mathrm{~A}$ & $100 \mathrm{C}$ & $6.7 \mathrm{D}$ & $117 \mathrm{~A}$ & $100 \mathrm{C}$ & $6.7 \mathrm{BC}$ & $134 \mathrm{~A}$ & $100 \mathrm{~A}$ \\
\hline & 14 & $6.8 \mathrm{~B}$ & $120 \mathrm{~A}$ & $413 \mathrm{AB}$ & $6.9 \mathrm{CD}$ & $117 \mathrm{~A}$ & $116 \mathrm{C}$ & $7.0 \mathrm{~B}$ & $134 \mathrm{~A}$ & $10 \mathrm{C}$ \\
\hline & 60 & $6.9 \mathrm{AB}$ & $140 \mathrm{~A}$ & $492 \mathrm{~A}$ & $7.2 \mathrm{AB}$ & $127 \mathrm{~A}$ & $204 \mathrm{AB}$ & $6.7 \mathrm{C}$ & $102 \mathrm{~A}$ & $37 \mathrm{BC}$ \\
\hline & 120 & $6.9 \mathrm{AB}$ & $161 \mathrm{~A}$ & $553 \mathrm{~A}$ & $7.3 \mathrm{~A}$ & $107 \mathrm{~A}$ & $140 \mathrm{BC}$ & $7.2 \mathrm{~A}$ & $113 \mathrm{~A}$ & $47 \mathrm{~B}$ \\
\hline & 180 & $7.1 \mathrm{~A}$ & $122 \mathrm{~A}$ & $203 \mathrm{BC}$ & $7.1 \mathrm{AB}$ & $171 \mathrm{~A}$ & $163 \mathrm{ABC}$ & $7.2 \mathrm{~A}$ & $93 \mathrm{~A}$ & $110 \mathrm{~A}$ \\
\hline & 240 & $7.1 \mathrm{~A}$ & $102 \mathrm{~A}$ & $167 \mathrm{C}$ & $7.1 \mathrm{BC}$ & $109 \mathrm{~A}$ & $219 \mathrm{~A}$ & $7.3 \mathrm{~A}$ & $105 \mathrm{~A}$ & $46 \mathrm{~B}$ \\
\hline
\end{tabular}

${ }^{\mathrm{a}}$ Values with the same capital letter do not significantly differ over time, i.e., within the column $(\mathrm{p}<0.05),{ }^{\mathrm{b}}$ WHC: Water holding capacity $(\%)$.

Table 2 - Pearson's correlation coefficient and p value between viability and viscosity, WHC or pH for the strains R. etli CFN42 ${ }^{\mathrm{T}}$, S. mexicanum ITTG $\mathrm{R} 7^{\mathrm{T}}$, and $R$. calliandrae LBP2-1 ${ }^{\mathrm{T}}$ kept on PEAT, PSB, CMCS, and YEMM for 240 days.

\begin{tabular}{|c|c|c|c|c|c|c|c|}
\hline \multirow[b]{3}{*}{ Carrier } & & \multicolumn{6}{|c|}{ Viability } \\
\hline & & \multicolumn{2}{|c|}{ R. etli $\mathrm{CFN} 42^{\mathrm{T}}$} & \multicolumn{2}{|c|}{ S. mexicanum ITTG $\mathrm{R} 7^{\mathrm{T}}$} & \multicolumn{2}{|c|}{ R. calliandrae $\mathrm{LBP} 2-1^{\mathrm{T}}$} \\
\hline & & $R$ value & $\mathrm{p}$ value & $R$ value & $\mathrm{p}$ value & $R$ value & $\mathrm{p}$ value \\
\hline \multirow[t]{2}{*}{ YEMM } & $\mathrm{pH}$ & 0.969 & $<0.001$ & 0.324 & 0.189 & 0.737 & $<0.001$ \\
\hline & Viscosity & -0.280 & 0.261 & -0.560 & 0.019 & -0.498 & 0.036 \\
\hline \multirow[t]{2}{*}{ CMCS } & $\mathrm{pH}$ & 0.335 & 0.175 & -0.198 & 0.432 & -0.837 & $<0.001$ \\
\hline & Viscosity & -0.609 & 0.007 & 0.942 & $<0.001$ & 0.966 & $<0.001$ \\
\hline \multirow[t]{2}{*}{ PSB } & $\mathrm{pH}$ & -0.323 & 0.191 & 0.053 & 0.835 & 0.361 & 0.141 \\
\hline & WHC & -0.084 & 0.740 & 0.254 & 0.310 & 0.495 & 0.037 \\
\hline \multirow[t]{2}{*}{ PEAT } & $\mathrm{pH}$ & -0.140 & 0.579 & 0.626 & 0.006 & 0.159 & 0.526 \\
\hline & WHC & 0.253 & 0.310 & -0.097 & 0.702 & -0.128 & 0.613 \\
\hline
\end{tabular}


Plant growth, nodulation and nitrogen fixation of Phaseolus vulgaris inoculated with different biofertilizers

Plants treated with strain $\mathrm{CFN}_{2} 2^{\mathrm{T}}$ stored in the CMCS carrier had the highest dry weight $(0.83 \mathrm{~g})$ (Figure 2). The CMCS carrier is a polymer blend, which favors the survival of the bacteria and the nodulation of different legumes, while the starch served as a $\mathrm{C}$ substrate (Fernandes-Júnior, 2009). Aeron et al. (2012) reported that Mucuna pruriens plants inoculated with Ensifer meliloti RMP6 and Bradyrhizobium sp. BMP7 ${ }^{\mathrm{T}}$ strains kept in a CMC carrier significantly increased plant biomass, the number of nodules and other plant growth parameters. The R. etli strain $\mathrm{CFN} 42^{\mathrm{T}}$, in combination with other diazotrophic bacteria, has a positive effect on the development of
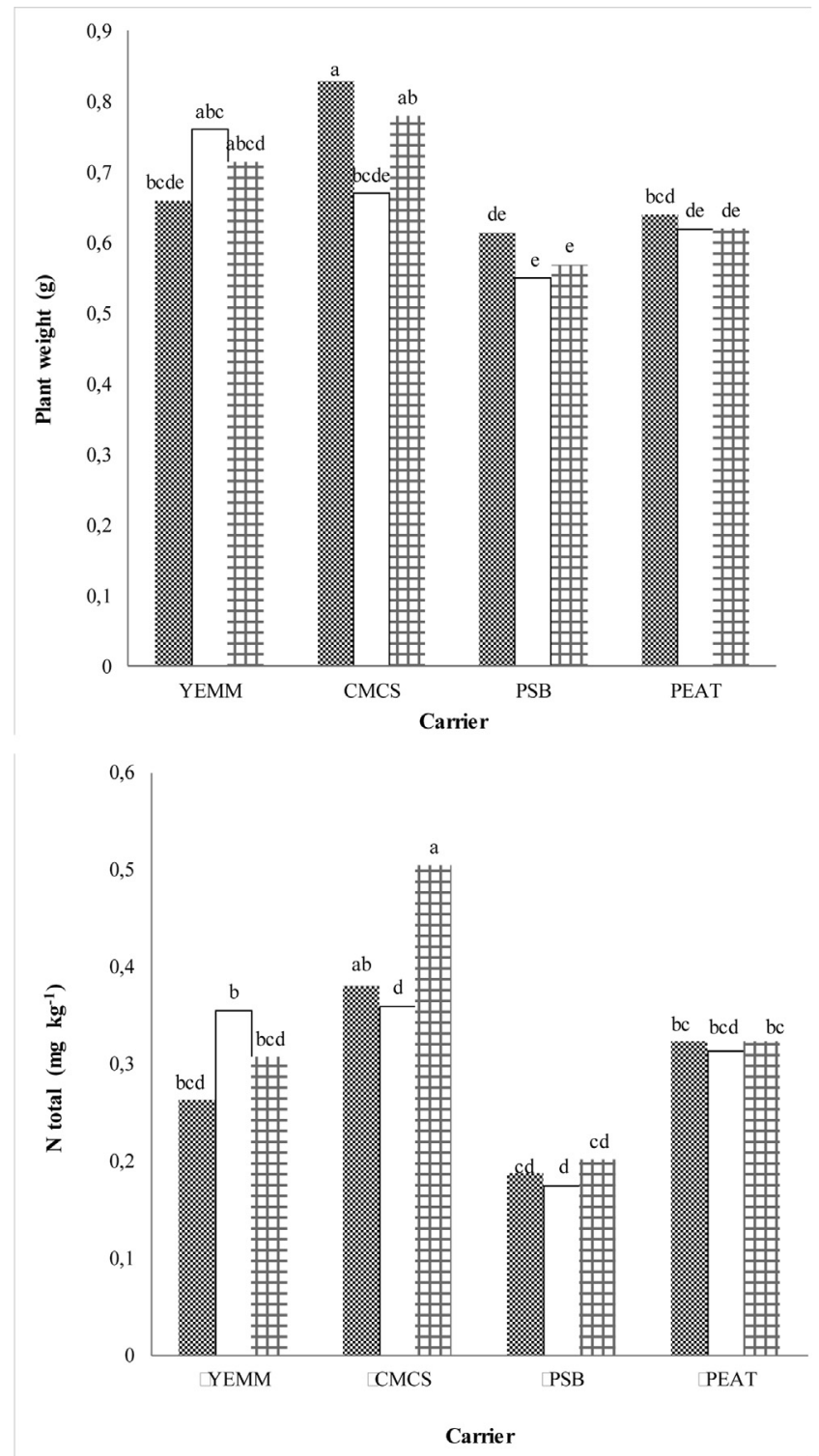

various legume and non-legume plants (Rosenblueth and Martinez-Romero, 2004).

All the strains kept on the different carriers effectively nodulated bean plants; however, the number of nodules formed was highest when inoculated with strain ITTG $\mathrm{R} 7^{\mathrm{T}}$ kept on the PSB carrier $(\mathrm{p}<0.05)$. PSB is a carrier that provides stability to the bacterial cells and essential nutrients for symbiotic $\mathrm{N}_{2}$ fixation while maintaining cell viability during infection and nodule formation on the host plant (Khavazi et al., 2007). The $\mathrm{N}$ fixed by inoculated plants was significantly different between the treatments $(\mathrm{p}<0.05)$. Plants inoculated with LBP2 $-1^{\mathrm{T}} \mathrm{kept}$ on CMCS fixed the largest amount of $\mathrm{N}\left(0.50 \mathrm{mg} \mathrm{kg}{ }^{-1}\right)$. RincónRosales et al. (2013) reported similar findings and found that the $R$. calliandrae strain LBP2-1 $1^{\mathrm{T}}$ isolated from the tropical legume Calliandra grandiflora grown in acidic
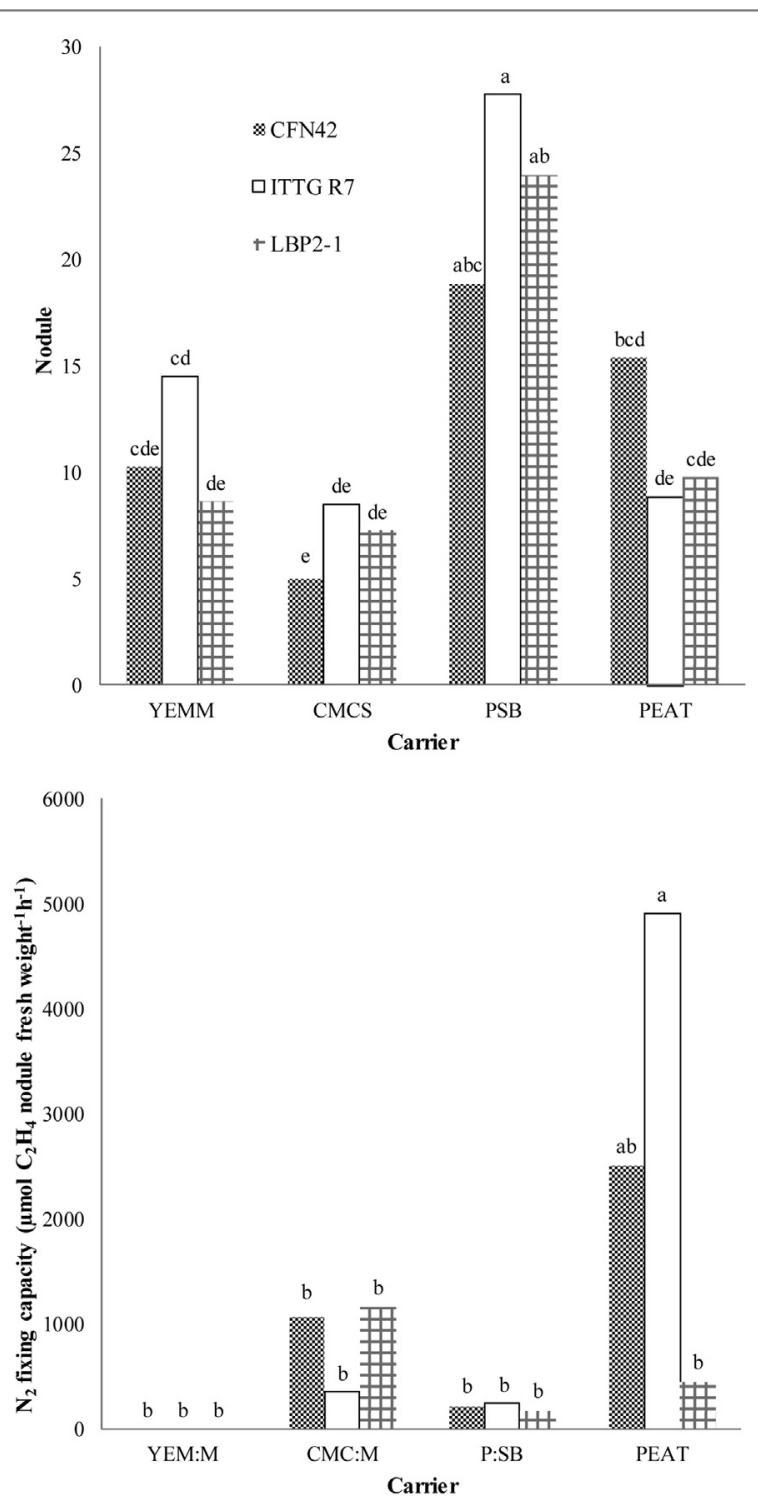

Figure 2 - Plant growth, nodulation and nitrogen fixation of Phaseolus vulgaris cv. Jamapa inoculated with different rhizobial strains. 
soil and with high amounts of aluminum had a high potential for nodulation and nitrogen fixation.

The nitrogenase activity was higher in bean plants inoculated with the ITTG $\mathrm{R}^{\mathrm{T}}$ strain kept on peat. As mentioned before, peat is a commonly used carrier due to its favorable characteristics (Khavazi et al., 2007; Ferreira et al., 2010). Lloret et al. (2007) reported that the strain ITTG $\mathrm{R} 7^{\mathrm{T}}$ has high nitrogenase activity and nodulation capacity when used to inoculate $P$. vulgaris and other tropical legumes.

\section{Conclusions}

Peat and perlite sugarcane bagasse were shown to be the most appropriate carriers to store the rhizobial strains (2 $\mathrm{x} 10^{9}$ cells $^{-1}$ ) and to maintain their survival. Strains Sinorhizobium mexicanum ITTG $\mathrm{R} 7^{\mathrm{T}}, R$. calliandrae LBP2- $1^{\mathrm{T}}$ and $R$. etli CFN $42^{\mathrm{T}}$ kept on perlite sugarcane bagasse induced the largest number of nodules in the common bean; however, their $\mathrm{N}_{2}$ fixation capacity was lower than when the strains were kept on peat. Consequently, no direct relationship existed between nodule formation in the host plant and $\mathrm{N}_{2}$ fixation capacity.

\section{Acknowledgments}

We thank M.A. Rogel-Hernández for technical assistance. This research was funded by Consejo Nacional de Ciencia y Tecnología (CONACyT, Mexico) and by Dirección General de Educación Superior Tecnológica (DGEST-SEP, Mexico). L.A.C.S. received grant-aided support from CONACyT.

\section{References}

Albareda M, Rodríguez-Navarro DN, Camacho M et al. (2008) Alternatives to peat as a carrier for rhizobia inoculants: Solid and liquid formulations. Soil Biol Biochem 40:2771-2779.

Aeron A, Khare E, Arora NK et al. (2012) Practical use of CMC-amended rhizobial inoculant for Mucuna pruriens cultivation to enhance the growth and protection against Macrophomina phaseolina. J Gen Appl Microbiol 58:121127.

Ben Rebah F, Tyagi RD, Prevost D (2002) Wastewater sludge as a substrate for growth and carrier for rhizobia: the effect of storage conditions on survival of Sinorhizobium meliloti. Bioresour Technol 83:145-151.

Ben Rebah F, Prevost D, Yezza A et al. (2007) Agro-industrial waste materials and wastewater sludge for rhizobial inoculant production: a review. Bioresour Technol 98:3535-3546.

Deaker R, Roughley RJ, Kennedy IR (2004) Legume seed inoculation technology a review. Soil Biol Biochem 36:12751288 .

Fahraeus G (1957) The infection of clover root hair by nodule bacteria studied by a single glass slide technique. J Gen Microbiol 16:374-381.

Fernandes-Júnior PI, Gusmão RT, Jansen de Oliveira P et al. (2009) Polymers as carriers for rhizobial inoculant formulations. Pesqui Agropecu Bras 44:1184-1190.
Fernandes-Júnior PI, da Silva Júnior EB, da Silva Júnior S et al. (2012) Performance of polymer compositions as carrier to cowpea rhizobial inoculant formulations: Survival of rhizobia in pre-inoculated seeds and field efficiency. Afr J Biotechnol 11:2945-2951.

Ferreira EM, Castro IV (2005) Residues of the cork industry as carriers for the production of legumes inoculants. Silva Lusitana 13:159-167.

Ferreira JS, Baldani JI, Baldani VLD (2010) Selection of peats inoculants with diazotrophic bacteria in two rice varieties. Acta Scientiarum Agronomy 32:179-185.

Flores da Silva M, de Souza AC, Jansen de Oliveira P et al. (2012) Survival of endophytic bacteria in polymer-based inoculants and efficiency of their application to sugarcane. Plant Soil 356:231-243.

Hungria M, Loureiro MF, Mendes JC et al. (2005) Inoculant preparation, production and application, In: Werner D, Newton WE (eds). Nitrogen Fixation in Agriculture, Forestry, Ecology and the Environment, Springer, Netherlands, 223-253.

Kaira A, Chandra M, Awasthi A et al. (2010) Natural compounds enhancing growth and survival of rhizobial inoculants in vermicompost-based formulations. Biol Fertil Soils 46:521-524.

Khavazi K, Rejali F, Seguin P et al. (2007) Effects of carrier, sterilization method, and incubation on survival of Bradyrhizobium japonicum in soybean (Glycine max L.) inoculants. Enzyme Microb Tech 41:780-784.

Lloret L, Ormeño-Orrillo E, Rincón R et al. (2007) Ensifer mexicanum sp. nov. a new species nodulating Acacia angustissima (Mill.) Kuntze in Mexico. Syst Appl Microbiol 30:280-290.

Lopez-Lopez A, Rogel MA, Ormeno-Orrillo E et al. (2010) Phaseolus vulgaris seed-borne endophytic community with novel bacterial species such as Rhizobium endophyticum sp. nov. Syst Appl Microbiol 33:322-327.

Luque-Castellane TC, Franco-Lemos MV, de Macedo-Lemos EG (2014). Evaluation of the biotechnological potential of Rhizobium tropici strains for exopolysaccharide production. Carbohydr Polym 111:191-197.

Martínez-Romero E (2003) Diversity of Rhizobium-Phaseolus vulgaris symbiosis: overview and perspectives. Plant Soil 252:11-23.

Rincón-Rosales R, Villalobos-Escobedo JM, Rogel MA et al. (2013) Rhizobium calliandrae sp. nov., Rhizobium mayense sp. nov. and Rhizobium jaguaris sp. nov., rhizobial species nodulating the medicinal legume Calliandra grandiflora. Int J Syst Evol Microbiol 63:3423-3429.

Rincón-Rosales R, Lloret L, Ponce RE et al. (2009) Rhizobia with different symbiotic efficiencies nodulate Acaciella angustissima in Mexico including Sinorhizobium chiapanecum sp. nov. that has common symbiotic genes with $S$. mexicanum. FEMS Microbiol Ecol 64:1-14.

Romdhane SB, Aovani ME, Trabelsi M et al. (2008) Selection of high nitrogen-fixing rhizobia nodulating chickpea (Cicer arietinum) for semi-arid Tunisia. J Agron Crop Sci 194:413-420.

Rosenblueth M, Martínez-Romero E (2004) Rhizobium etli maize populations and their competitiveness for root colonization. Arch Microbiol 181:337-344.

Ruiz-Valdiviezo VM, Ayora-Talavera TR, Gutiérrez-Miceli FA et al. (2009) Effects of inorganic fertilizers and rhizobial in- 
oculation on growth, nodulation and tannin content of Acaciella angustisima (Mill.) Britton \& Rose. Gayana Bot 66:206-217.

Skorupska A, Janczarek M, Marczak M et al. (2006) Rhizobial exopolysaccharides: genetic control and symbiotic functions. Microb Cell Fact 5:1-19

Somasegaran P, Hoben HJ (1985) Methods in legume-rhizobium technology. United States Agency for International Development, USA.

Swelim DM, Nassef MA, Elkhatib EI (2010) Survival and shelf life of leguminous trees rhizobia as affected by sterilization, culture dilution and maltose and trace elements enriched carrier. J Appl Sci Res 6:1366-1372.
Tittabutr P, Payakapong W, Teaumroong N et al. (2007) Growth, Survival and field performance of bradyrhizobial liquid inoculant formulations with polymeric additives. Sci Asia 33:69-77.

Topre SD, Panikar SS, Mahajani SU et al. (2011) Biofertilizer: A novel approach for agriculture. J Agric Biotech Sustain Dev 3:205-208.

Vincent JM (1970) A manual for the practical study of root nodule bacteria. Oxford: Blackwell Scientific Publications.

Associate Editor: Valeria Maia de Oliveira

All the content of the journal, except where otherwise noted, is licensed under a Creative Commons License CC BY-NC. 